\title{
J.H. le Roux's philosophy of religion
}

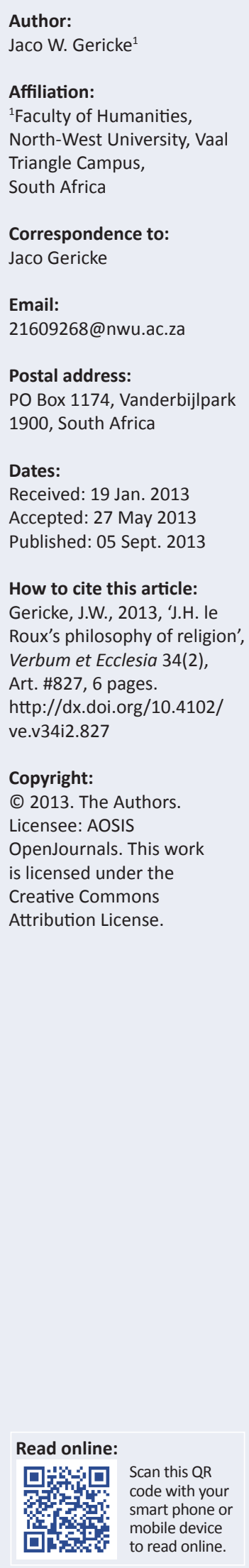

J.H. le Roux had a passion for philosophy. His writings contain recourse to the history of philosophy in a way that bespeaks a deep underlying interest in the subject. This much is relatively well-known. This contribution, by contrast, aims at reconstructing something hitherto mostly covert: Le Roux's philosophy of religion. Of interest is what his writings presuppose about the nature of religion, religious language, the nature of God, the existence of God, religious epistemology, the relation between religion and morality and the problem of religious pluralism.

\section{Introduction}

J.H. le Roux is one of few Old-Testament scholars with an intense interest in philosophy. Not surprisingly, colleagues have noted his passion for aspects of Continental philosophy in particular. For example, according to Lombaard (2006:917), it is, '... natuurlik vir Le Roux om deur ... die moderne Franse eksistensialiste heen die Bybelteks eietyds te aktualiseer. Hermeneutiek en dus filosofie, ook wetenskapsfilosofie, is hiervoor onontbeerlik.'

A somewhat more detailed outline of Le Roux's philosophical biography is found in part of the dedication written by Human (2006):

Jurie se belangstelling in Filosofie is bekend. In 1994 behaal hy 'n Honneursgraad in Filosofie aan die Universiteit van Suid Afrika. Hy bly steeds 'n aktiewe filosofiestudent wat ook filosofiese hermeneutiek in die teologiese opleiding van studente aan die Universiteit van Pretoria doseer. Filosofie is die asem waaruit Jurie sy teologie bedryf. Daarom is gereelde gesprekke met filosowe en filosofiese byeenkomste by Café Riche in Pretoria deel van sy lewensritme. Die invloed van onder andere Karl Jaspers, Martin Heidegger en Hans-Georg Gadamer lê in Jurie le Roux se akademiese mondering ingebed. Ons kan die name van Jean-Paul Sartre, Albert Camus, Jacques Derrida en talle ander hierby voeg. Dit was Heidegger se onderskeiding tussen rekende denke en denkende denke wat vir Le Roux 'n inspirasie in sy wetenskapbeoefening was aangesien hy die denkende denke as basis vir sy eie teologie-bedryf en wetenskapsbeoefening nastreef. Die nadenke oor denke behoort volgens Jurie die norm vir goeie akademiese werk wees. [Jurie's interest in philosophy is well-known. In 1994, he obtained an honours degree in philosophy at the University of South Africa. He still remains an active philosophy student who also teaches philosophical hermeneutics in the theological training of students at the University of Pretoria. Philosophy is the breath from which Jurie practices his theology. That is why frequent discussions with philosophers and philosophical meetings at Cafe Riche in Pretoria are part of the rhythm of his life. The influence from, amongst others, Karl Jaspers, Martin Heidegger and Hans-Georg Gadamer is engrained in Jurie's academic armour. We may also add the names of Jean-Paul Sartre, Albert Camus, Jacques Derrida and many others. It was Heidegger's distinction between reasoned and contemplative thought which served as inspiration for Jurie in his scientific thinking as he strives toward the latter in his theology. The reflection on thought is, according to Jurie, the norm for good academic work.] (p. 809, [author's own translation])

The present author's own memories of Le Roux's academic persona concur with these observations. In many Old-Testament classes, already at undergraduate level, Le Roux fascinated students with the ideas of his philosophical mentors. This created a hermeneutical, epistemological and existential context for the Old Testament component of his lectures. Le Roux also went the extra mile, and in compiling new study guides almost every year, he would share relevant insights from the history of Western philosophy. Because Le Roux felt South African culture had missed the impact of the Enlightenment, a philosophical contextualisation of Old Testament studies for mostly fundamentalist students made much sense. Always a humble yet prophetic voice, whilst a generation of students were being trained on a staple diet of structuralist exegesis, Le Roux's hermeneutics were anomalously post-structuralist and beyond.

\section{Le Roux's philosophy of religion}

Whilst Le Roux's philosophical interests have been noted by himself and others, his views concerning issues in the analytic philosophical sub-discipline known as philosophy of religion remain unreconstructed. This is not surprising as several factors make Le Roux's Religionsphilosophie 
covert and complicated in its dissemination. Firstly, because Le Roux's thought is fed primarily by the so-called Continental trajectories in philosophy (except for his reliance on assorted bits of analytic thought in the philosophy of science), his philosophy of religion is mixed into his philosophical ideas on other subjects. Hence it is not easy to infer what he took for granted about issues on the agenda in analytic Christian philosophy of religion (see Trakakis 2008:1-47 for the analytic-Continental divide in the subject).

Secondly, whilst Le Roux's writings attest to an interest in various philosophical matters, one will look in vain for any explicit and systematic exposition of his philosophy of religion. His thought is, like the Old Testament itself, plural, elusive and multiplex. Hence what must be done involves a reconstruction of a stereotype of what Le Roux seems to have assumed with reference to topics on the agenda in mainstream Anglo-Saxon philosophy of religion. Thirdly, Le Roux's thought is not static, and one might even speak of earlier, middle and later trajectories in his philosophical biography. This despite several interests remaining common to all phases of his intellectual journey. Fourthly, Le Roux's particular approach to religious ideas is rather unique in the sense that it overflows the categories of stereotypical Continental thought on religion - he never blindly followed any single thinker all the way. He was too historically conscious for that (cf. Le Roux 1993b).

Due to the aforementioned complications, the present reconstruction of Le Roux's philosophy of religion is of necessity a risky, presumptuous and partly speculative enterprise. Moreover, it is embarked on by someone who was born too late to be acquainted with him intimately enough to write with confidence. Since what I know of Le Roux's philosophy of religion is only what can be gainsaid from personal experience and from the interpretation of his writings, it seems impossible to do justice to the synchronic complexity and diachronic pluralism in the thoughts of a man whose theological 'self' is as elusive and fluid as any radically fragmented postmodern subject. Yet it is also Le Roux, perhaps more than anyone else, who will appreciate the fact that who we are forever exceed our ability to capture this existence in language. We know Le Roux only through our theories (cf. Le Roux 2001:444).

\section{Issues on the agenda}

Le Roux's philosophy of religion remains in some sense the sine qua non of his thought. For that reason, in the discussion to follow, I shall seek to reconstruct what I interpret to be some of Le Roux's assumptions about the nature of religion, religious language, the attributes and existence of God, religious epistemology, the relation between religion and morality and the problem of religious pluralism.

\section{The nature of religion}

Contrary to what is implicit in Le Roux's passion for historical criticism (and therewith a modernist epistemology), he also has immense appreciation for the post-critical naiveté of postmodernism (particularly in its deconstructive format) (Le Roux 1991a:103-105). Because of this, he is very much aware that religion is an all-too-human phenomenon (Le Roux 1994a:27-37). This is the case, even if the religious object is not (see Le Roux 2004b:743-753). If, therefore, Le Roux was asked to offer a definition of religion, he might have ventured a non-essentialist explication along Schleiermachian lines, linking it to spirituality and to empathetic feeling and imagination (Le Roux 1998b:477-486).

Yet for Le Roux, there will be no place for sociological or psychological reductionism (as with e.g. Durkheim and Freud) (see Le Roux 1971). Neither would he feel comfortable with defining religion along any purely theological or dogmatic lines (see Le Roux 2003:124-136). Eschewing any attempt to capture in language a phenomenon so complex and historically variable, Le Roux might have concurred with Derrida and his followers that the nature of religion is best witnessed to by mystics and the negative theology for it is concerned with the 'impossible' (in the sense used by Derrida and Caputo).

\section{The nature of religious language}

Reading between the lines of his work, it would seem that, for Le Roux, god-talk is not fact-stating (see Le Roux 1998a:120-131). Since Le Roux is anti-positivist, the verificationist and falsificationist principles put up by logical positivism and empiricism cannot be invoked as challenges to the meaningfulness of religious language. Even Le Roux's affinity for Popperian falsification seems limited to the philosophy of science and presumably does not extend to his views on the logical status of god-talk in philosophy of religion (see Le Roux 1993b:67).

Overall, however, between the lines, Le Roux's writing on religion breathes a non-cognitivist perspective typical of Continental philosophers of religion (following Kant's critique of transcendental pretence and Heidegger's case against onto-theology). Whilst for Le Roux, god-talk does refer and God in re has ontological status, from the point of view of Le Roux's 'soft' historicist metaphysics, all our language about God, like our language about anything else, cannot be 'factual' or 'objective'(Le Roux 2001:444-457). That is, in other words, religious language is not something that corresponds with a mind-independent reality studied by impartial and disinterested investigation. However, as Le Roux's writings imply, his position is not to deny the possibility of religious language being meaningful but to reconfigure religious truth in practical or existential, as opposed to purely theoretical, terms (Le Roux 1990:49, 1998c:456).

Religious truth, on Le Roux's view, is not to be assigned to the category of descriptive formalities that get things right, once and for all. Rather, religious language's meaningfulness belongs to the order of faith and religious experience, not knowledge, so that it is a matter of testifying to what is confessed to be the love of God (Le Roux 1994b:56-67, 
1994c:11-27). This explains the difference between Le Roux's god-talk when he uses religious language historically and descriptively to clarify how past figures in the tradition have spoken, as opposed to when Le Roux speaks expressively and personally with regard to what he himself believes at any given time. To confuse the two is to create contexts for great misunderstanding (especially by fundamentalist students and colleagues) (see Le Roux 1993a:11-27, 1997:11-31).

Whilst Le Roux (1993b:passim) is opposed to the metaphysical assumptions of structuralism and links up with postmetaphysical, post-structuralist thinkers, he differs from discursive idealists and linguistic naturalists in that he does think the divine is something outside of religious language (Le Roux 1994b:65). Here he stands in line with the tradition from Augustine to Gadamer, all of whom would deny that language is ever enough to capture the religious object which is always deferred, other, mysterious and beyond our grasp (see Le Roux 2004a:123-130).

As a result, for Le Roux, religious language is not univocal. Whether he would consider it to be analogical or equivocal is unsure. On another spectrum, it is equally unclear whether Le Roux would consider concepts such as metaphor, symbol, myth or some such term adequate to the task of capturing the multiplex nature of religious language. What is certain is that, for Le Roux, as for some leading medieval philosophers, the infinitive qualitative difference between divine and human engenders the problem of religious language (cf. Le Roux 1994b:60). It might therefore perhaps be best to say that Le Roux's conception of religious language is that it is expressive rather than descriptive.

\section{The nature of God}

For Le Roux, 'God' is a concrete, not abstract, reality (see Le Roux 1994b:12). Yet the divine is more a mystery to be experienced, not a problem to be solved (as with Jaspers). Le Roux knows that philosophical conceptions of divinity tend to be abstractions, that is God as the Unmoved Mover, the One, the Supreme Being, the Absolute Spirit or the First Cause. Such a God, as Heidegger recognised, is religiously useless (cf. Le Roux 1994b:14). Thus Le Roux's would in all likelihood concur with contrasting the perfect-being theology of some philosophical theologians with the theologies of biblical spiritualities (cf. Le Roux 2003:125). For Le Roux, as for Augustine, Barth, Heidegger, Levinas and Derrida, God is absolutely other (Le Roux 1994b:59). However, the conception of God as such implies not merely that the standard philosophical definitions of God are inadequate but that the very attempt to delimit God by means of definition fails to take due notice of the profound mystery that is God. The otherness of God, for Le Roux, also manifests itself in our ignorance as to who or what God is (Le Roux 1994b:56).

One can therefore speak of God as having attributes, yet Le Roux is never interested in the metaphysics of this context. Most of his god-talk is concerned with positive divine attributes such as divine love and grace, and he is acutely aware of divine hiddenness and absence (Le Roux 1990:48-57). Le Roux's philosophical theology is therefore strongly reminiscent of the mystics and apophatic theology, the traditions of which hold that it is very hard to say what God is actually like (Le Roux 2004a:128-129). There is little interest in proclaiming or debating the intricacies of the classical theism ideas of divine personality, omnipotence, omniscience, perfect goodness, aseity, incorporeality and all the philosophical riddles to which such properties and their conjunction give rise.

There is too much complexity in his writings to label Le Roux with any more detail or to put his natural theology in the confines of a particular philosophical theology's thinker or school of thought (e.g. Pannenberg). Whilst his discussions of biblical theology are descriptive and full of inspiring historical confessions, the extent to which his personal beliefs about the divine nature fit into any of the popular and stereotypical categories of philosophical monotheism remains an open question (see Le Roux 1994b:56-67).

\section{The existence of God}

Because Le Roux follows the spirituality of Von Rad's Barthian-Kierkegaardian bracketing of natural theology, his writings show little interest in defending any particular views regarding the existence of God. In it, however, one also finds a distinction between the descriptive Le Roux who talks as though Yahweh as depicted actually exists and the evaluative Le Roux who, when pressed, might be more of a critical-realist or even agnostic about the relationship of biblical characterisations to extra-textual reality. Le Roux is definitely theistic as opposed to atheistic in that he believes that God (whatever one understands by this) exists (whatever his ontological status). This is the case even though theology is, for him, a constructive enterprise, and he ever-so-pastorally locates himself in a space beyond the supernaturalism of traditional Christian thought (Le Roux 1993a:11-27, 1997:11-31).

For Le Roux (2002:383) as for Heidegger and other Continental postmodern and post-metaphysical thinkers, God is therefore technically not an existent or a being. To treat God as an object, a thing or a being who exists amongst other beings is to reduce God to creaturely proportions. Le Roux thus refuses to place God in the same ontological order as ordinary beings and objects (see Le Roux 1994b:62). In the Continental tradition, this is customarily expressed as a refusal to conceive of God in metaphysical or ontotheological categories. But to Le Roux, this does not require the theologian to deny the reality of God or to adopt an antirealist approach to the ontological status of the divine where the deity itself is reduced to a metaphor or a projection of human wishes or some sort of fiction. The latter may be the fate of our theological constructs, but Le Roux would refuse to delimit the reality of God within the horizon of being, presence, power and causality (see Le Roux 1991b:277). With Kant, Le Roux is happy to admit the limitations of human reason. 


\section{Religious epistemology}

As noted earlier, Le Roux's affinity for Gadamer (he is doing his third doctorate on him) would put him in the hermeneutic current in philosophy of religion (see Le Roux 2002:383-392). In this approach, one would say of religious knowledge that it is concerned with tradition and interpretation. Hence Le Roux is likely to think of religious truth claims as radically historically relative and its object forever eluding our theories and methodologies with which we try to grasp it. With Foucault, Le Roux would say that all god-talk is inextricably bound up with discourse and episteme (cf. Le Roux 2012:n.p.) Le Roux is therefore not without a healthy sceptical bent as far as knowledge of God is concerned. Yet with someone like Ricoeur, Le Roux has listened to and then moved beyond the masters of suspicion (Marx, Nietzsche, Freud) to a hermeneutics of recollection.

Perhaps because of his appreciation for the insights of Kuhn, for Le Roux (1991b:277), religious knowledge is not scientific in nature, even if biblical criticism aspires to the scientific ideal of obtaining justified true belief (see Le Roux 1998b:481). However, to construe religious beliefs as hypotheses, inferences or probability judgements is to model religious belief on the practice of science, a kind of scientism which the Continental tradition to which Le Roux adheres strongly disavows. For Le Roux, religious beliefs, unlike scientific theories, demand infinite commitment and passion, which is why one cannot imagine Le Roux treating theistic belief as a hypothesis that may furnish evidence in its favour. Belief does not become more probable or not in the light of the available evidence, with the believer all the whilst remaining personally indifferent to God (see Le Roux 1991b:282).

Since along with other post-modern thinkers Le Roux considers positivism outdated, the challenge of evidentialism will by implication not bother him. Faith is for him not a matter of proof. Nor would he consider religious knowledge to be justified true belief. For Le Roux, what one claims to know religiously is highly experiential and personal. This he might justify with an appeal to Gadamer and the hermeneutical relativising of all human knowledge, including religious knowledge (see Le Roux 2002:383-392). Hence one looks in vain in Le Roux's writings for thoughts on the analytic debates between externalists and internalists or for concerns with what actually happened in revelation or religious experiences (aside from historical-critical insights).

In other words, for Le Roux, the cognitive dimensions of religion are intricately linked to affective ones, and all knowledge is historical and interpretative (1991b:277-292). From his views in hermeneutics, philosophy of science and deconstruction, one may gather that religion, for him, is not about arriving at knowledge and truth. In fact, he wishes to be done with the cognitivism of oppressive epistemologically optimistic religious ideologies (see Le Roux 1998a:120-131). The only religious knowledge available is interpreted experience, mystery and finitude. Hence religious experiences are not taken to convey factual knowledge and are always coloured by tradition.
Le Roux concurrence with Foucault on the reality of episteme and his dismissal of truth-via-method with Gadamer as noted earlier also suggests that, for Le Roux, technically there is no such thing as divine revelation that can be had objectively as total truth. There are only historical appeals to it - yet it is never in itself present to us (see Le Roux 1998c:449-458). As can be expected therefore, a strong anti-foundationalism is clearly discernible in Le Roux's writings (following Van Huyssteen 1997:124-161). No rock-bottom justification of religious beliefs is available. Hence whilst one will find many a seemingly naïvely traditional confession in Le Roux's contributions to theological discussions, a thousand and one qualifications exist.

\section{The relationship between religion and morality}

Le Roux's interest in the relationship between religion and morality is fed from many sources. One of these (besides the philosophical thinkers already mentioned) is Eckhart Otto's Old Testament ethics (see Le Roux 2005). Though meta-ethics is absent from much of the material, it would seem that, for Le Roux and with reference to the Euthyphro dilemma, God does not determine the nature of the good. The moral order is such that one can rebel against the divine. Yet Le Roux does not fall into moral realism and can transcend his cultural narrow-mindedness in that he recognises himself to be too much of a historical animal to claim to know God's will aside from human ideology (see Le Roux 1994a:27-37).

Since Le Roux shares the existentialists' idea that life is basically meaningless and that humans are radically free to create their own, the relationship between religion and morality in his writings is more complex than the prima facie case may seem to be. Paradoxically Le Roux would also affirm the hermeneutic and postmodern view that the Cartesian self - also the moral self - is dead. Our religious morality is always constructed within an already given socio-cultural matrix. Hence religious morality is always intricately tied up with episteme and discourse (Le Roux 2004b:743-753). By implication this means that there is no such thing as revealed universal and divine moral precepts waiting to be followed. Since we are both radically free yet also completely culturally constructed, Le Roux's moral philosophy is essentially emotivist and relativist, even if much of it resonates with the religious tradition.

With regard to the problem of evil and theodicy, it may be said that Le Roux's writings shows that he is acutely aware of the various dimensions of human suffering (see Le Roux 1993a:11-27). Whether one thinks of what is often distinguished as metaphysical, moral or natural evil, Le Roux will not deny that the divine cannot be counted on to prevent evil. Yet Le Roux never considers evil an argument against the existence of God like Sartre or Camus did. In fact, he finds in God a consolation without which he cannot live, even if it is love from a hidden god (see Le Roux 1990:48-57).

Though he does not offer any theodicy, Le Roux has wrestled with the problem of justice and shows a deep understanding 
of the absurdity of the human condition (our thrown-ness and the harsh reality of death, cf. Le Roux 1998c:449-458). However, instead of using such facticity as an objection to a belief in the essential goodness of the divine, Le Roux considers belief in God's love all the more necessary (Le Roux 1990:48-57). He also follows Job and Ecclesiastes in the belief that suffering is part of a bigger mystery and something one can only endure as part of the utterly fragile and contingent human condition. Here too, thought, there is a difference between the descriptive and evaluative Le Roux (see Le Roux 1994c:11-27). He can agree with Marcion that the God of the Old Testament can at times be evil, yet in another context, he finds in many representations of Yahweh a great comfort (Le Roux 2003:124-136).

\section{The problem of religious pluralism}

Le Roux is a Christian who is passionate about his faith. Yet his knowledge of the history of religion, sociology and philosophy has made him someone who will admit that Christianity in general and the Dutch Reformed Church to which he belongs in particular have no monopoly on the Divine (see already Le Roux 1971). Le Roux is intensely aware of how everyone is a child of their time and how every thinker operates within a tradition. Everything is seen only through theory (Le Roux 2001:444-457). This means that, for Le Roux, religious pluralism is no existential problem but exactly what one would expect from the religious diversity engendered by hermeneutics of reality.

Though he is no exclusivist and abhors fundamentalism, Le Roux is not an inclusivist in the sense that he has ever seemed to feel the need to investigate all religions and then to judge between them and/or to consider them to be equal paths to the same alleged ultimate reality. He seems only interested in the Judaeo-Christian legacy and never wrote anything indepth about Islam, Eastern or African traditional religions, et cetera in relation to his own faith. Yet, neither would he claim that others have no access to truth or engage in Foucauldian 'othering', damning all who differ from him to hell. Nor does he consider all religious beliefs to be equally valid along parallel lines. Consequently it might be most apt to classify Le Roux's thoughts on religious pluralism as endorsing the belief in interpenetration (according to the Pannikar popular fourfold model of exclusivism, inclusivism, parallelism, interpenetration) (see Le Roux 1991a:103-105).

\section{The philosophico-religious psychodrama of being Le Roux}

What often goes unnoticed in discussions of Le Roux's philosophy in relation to his own religion is the burden of the internalisation of so much history to his psyche. In his philosophical approach, Le Roux always considered empathy with those under scrutiny a necessary condition for a certain kind of historical understanding. In this section, I would like us to consider with empathy Le Roux's philosophical profile. I might be mistaken, but from the perspective of a historicalphilosophical genealogy of Le Roux's philosophical-religious psychology, it cannot be easy to be the philosophical Le Roux. One not only encounters a spirit of tremendous wisdom and humility, one also finds someone who cannot but become world weary, as though having to have lived through all the thinkers of the entire history of ideas. Having internalised virtually each intellectual revolution of the history of dogma in his own body, having immersed himself in the history of Israel and the Church, of philosophy and the sociology of religion, Le Roux's philosophy of religion has the battle scars to show for it. One might rightly speak here with reference to Le Roux as him being a personification of the passion of the western mind.

Le Roux's philosophical-religious profile reveals a man who appears to carry an intellectual load beyond what most people would survive without losing their mind. Raised in the context of religious fundamentalism and pietism, Le Roux had the courage to immerse himself in (1) Kantian anti-transcendentalist agnosticism, (2) romanticism's futile desire to relive the past, (3) secular French existentialism's sense of futility, alienation, absurdity and thrownness, (4) Heideggerian-Gadamerian hermeneutics' understanding that the serious core-beliefs of each person are chaff in the wind (Koos du Plessis' 'Kinders van die Wind' comes to mind), (5) Ricoeurian hermeneutics of suspicion's demythologising of our pretences (through Marx, Nietzsche, Freud) and (6) post-structuralism's views of the relationship between knowledge and power (Foucault) and the deconstruction of the metaphysics of presence and logocentrism; hence a perpetual mourning and sense of loss.

Hence Le Roux's philosophy of religion betrays a fragmented postmodern subject battered by one too many paradigm shift and scattered across time. The sense of alienation from popular Afrikaner, African and Western culture must be enormous, the sense of diffused identity surreal and the feeling of radical contingency paralysing. As with Derrida, Le Roux's philosophical theology is a hauntology that must find it impossible to share in the consolations of being a theist in the traditional sense (Le Roux 1998b:477). Yet such existential fragility will also not be able to find in him the strength, rationale or the motivation to take seriously atheism and Nietzschean nihilism or Camus' absurdism. We thus encounter a combination of religious empathy and existential rebellion, both relativised by the realisation that we have lost the bigger picture (Sisyphus). The result is a 'weak' and mystical philosophical theologian (not in a pejorative sense), saturated with theo-politically broken dreams, lost hopes and faded grandeur.

\section{Conclusion}

It is my hope that, in making these inferences about Le Roux's covert philosophy of religion from a selection of his writings, I was not too presumptuous and that I did justice to a man whose intellect represents a library of Borgean proportions. In the end, what is left standing is J.H. le Roux's idiosyncratic philosophy of religion in which religion is all-too-human, religious language expressive, God a mystery and infinitely 
elusive reality, religious knowledge fragile, religious morality socially constructed and religious diversity the expected outcome of contextual relativism.

What is clear is that Le Roux's philosophy of religion is not readily accessible but lies nascent and covert in his writings. Continental rather than analytic in flavour, Le Roux's criticalrealism cannot be stereotyped to fit exactly into the mould of any existing religious thinker or school of thought. Le Roux's philosophical theology is far too complex for that, and reading between the lines, one is entranced by a joyful shadow play of signification, creating riddling ripples on the silence of eternity.

\section{Acknowledgements Competing interests}

The author declares that he has no financial or personal relationship(s) that may have inappropriately influenced him in writing this article.

\section{References}

Human, D.J., 2006, 'Jurie Hendrik Le Roux: Deernisvolle mens en veelsydige akademikus', Old Testament Essays 19(3), 801-819.

Le Roux, J.H., 1971, 'n Godsdienssosiologiese ontleding van Max Weber se stelling dat Protestantisme verantwoordelik is vir kapitalisme, MA-verhandeling, Departement Sosiologie, Universiteit van Pretoria, Pretoria.

Le Roux, J.H., 1990, 'Eensaamheid in lyding', in C.J.A. Vos \& J.C. Müller (reds.), God in ons lyding, bl. 48-57, Orion, Pretoria.

Le Roux, J.H., 1991a, 'The interrelatedness of human beings: A response to Adrio König', Journal of Theology for Southern Africa 76, 103-105.

Le Roux, J.H., 1991b, 'Oor paradigmas en progressie in die teologie', Skrif en Kerk 12(2), 277- 292
Le Roux, J.H., 1993a, 'Waar is die bose magte dan?', in S.J. Joubert \& J.G. van der Watt (reds.), Satan ontbloot, bl. 11-27, CUM, Vereeniging.

Le Roux, J.H., 1993b, 'A story of two ways. Thirty years of Old Testament scholarship in South Africa', Old Testament Essays, suppl. ser. 2, Verba Vitae, Pretoria.

Le Roux, J.H., 1994a, 'God se brug na die mens: lets goddeliks of iets menslik', Skrif en Kerk 15(1), 27-37.

Le Roux, J.H., 1994b, 'Die grote God en die kleine mensie', in C.J.A. Vos \& J.C. Müller (reds.), Menswaardig, bl. 56-67, Halfway House, Orion.

Le Roux, J.H., 1994c, 'God is in beheer', in S.J. Joubert \& J.G. van der Watt (reds.), Wanneer jy vra waarom?, bl. 11-27, CUM, Vereeniging.

Le Roux, J.H., 1997, 'Engele en die Ou Testament', in S.J. Joubert \& J.G. van der Watt (reds.), Hy sal sy engel voor jou uitstuur, bl. 11-31, CUM, Vereniging.

Le Roux, J.H., 1998a, 'Verlos ons van die waarheid. Fragmente 2', Tydskrif vir Filosofie en Kultuurkritiek, 120-131.

Le Roux, J.H., 1998b, 'Israel's past and the feeling of loss (Or: Deconstructing the minimum of the minimalists even further)', Old Testament Essays 11(3), 477-486.

Le Roux, J.H., 1998c, 'Teologiekroniek', Skrif en Kerk 19(2), 449-458.

Le Roux, J.H., 2001, 'No theory, no science. (or: Abraham is only known through a theory)', Old Testament Essays 14(3), 444-457.

Le Roux, J.H, 2002, 'Hans-Georg Gadamer en die Ou Testament', Verbum et Ecclesia 23(2), 383-392.

Le Roux, J.H., 2003, 'Von Harnack, Marcion en die Ou Testament', Verbum et Ecclesia 24(1), 124-136. http://dx.doi.org/10.4102/ve.v24i1.317

Le Roux, J.H., 2004a, 'Augustine, Gadamer and the Psalms', in D.J. Human \& C.J.A. Vos (eds.), Psalms and liturgy, pp. 123-130, T\&T Clark, New York.

Le Roux, J.H., 2004b, 'Die mag van religieuse idees', HTS Teologiese/Theological Studies 60(3), 743-753. http://dx.doi.org/10.4102/hts.v60i3.611

Le Roux, J.H., 2005, 'Pro pent: A project for the study of the Pentateuch in South Africa', in E. Otto \& J.H. le Roux (eds.), A critical study of the Old Testament, pp. 1-21, Lit Verlag, Münster.

Le Roux, J.H., 2012, Geskiedenis van Ou Testament Eksegese 27 - Soek 'n teks se struktuur, viewed 12 December 2012, from http://teo.co.za/artikel/ articles/453/1/Geskiedenis-van-Ou-Testament-eksegese-27-Soek-n-teks-searticles/453/1/G1.html
struktuur/Bladsy-van-Ou-Testament-eksegese-27--Soek-n-teks-se-

Lombaard, C., 2006, 'JH le Roux se lees van die Bybel', Old Testament Essays 19(3), 912-925.

Trakakis, N., 2008, The end of philosophy of religion, Continuum, London.

Van Huyssteen, J.W., 1997, 'The realism of the text: A perspective on biblical authority', in J.W. van Huyssteen (ed.), Essays in postfoundationalist theology, pp. 124-161, Willaim B. Eerdmans Publishing Company, Grand Rapids. 